\title{
CORRELATION OF THE ERYTHROCYTE SEDIMENTATION RATE AND GOLD COMPLICATIONS IN RHEUMATOID ARTHRITIS
}

\author{
BY \\ LENNART KALLIOMÄKI \\ Medical Clinic of the University, Turku, Finland
}

(RECEIVED FOR PUBLICATION JULY 5, 1954)

Certain observations have been reported according to which complications in association with gold therapy in rheumatoid arthritis would seem to be inversely proportional to the erythrocyte sedimentation rate (Goldie, 1939; Ellman and others, 1940; Lawrence, 1953). This has been explained on the basis that a high E.S.R. is generally seen in the active exudative stage of the disease, and that the gold, which has become bound to the globulins, is then able to penetrate through the damaged capillaries into the diseased tissue. Consequently the gold concentration in the skin, bone marrow, and other tissues is unable to attain the same levels as when the E.S.R. is low and the disease is in a less active stage.

Since this point is an important one in clinical practice, I have observed the possible correlation of gold complications and E.S.R. in patients receiving continuous gold therapy at the Turku Polyclinic for Rheumatic Diseases.

\section{Material}

The series comprised 173 patients. The gold* was administered once weekly during 10-12 weeks and the 50-mg. limit was not exceeded. When a total dosage of $500 \mathrm{mg}$. had been reached, further administration was in the form of a so-called maintenance dosage of $50 \mathrm{mg}$. once a month.

\section{Results}

The Table shows the correlation between the incidence of gold complications and the erythrocyte sedimentation rate. In those cases in which there were no complications of this kind, the lowest E.S.R. during gold therapy was noted. In cases with complications, the E.S.R. registered during the occurrence of the complication was observed. Without exception all onsets of dermatitis during the gold therapy were taken into consideration. Itching

\footnotetext{
* The gold preparation used in all cases was Myocrisin (May and
}

without dermatitis was not considered a complica- $\vec{\omega}$ tion. There were no cases of thrombocytopenia in our series.

TABLE

INCIDENCE OF GOLD COMPLICATIONS RELATED TO ERYTHROCYTE SEDIMENTATION RATE

\begin{tabular}{|c|c|c|c|c|}
\hline \multirow{2}{*}{ Complication } & \multicolumn{2}{|c|}{ E.S.R. $\leqq 30 \mathrm{~mm} . / \mathrm{hr}$. } & \multicolumn{2}{|c|}{ E.S.R. $>30 \mathrm{~mm} . / \mathrm{hr}$. } \\
\hline & $\begin{array}{l}\text { No. of } \\
\text { Patients }\end{array}$ & Percentage & $\begin{array}{l}\text { No. of } \\
\text { Patients }\end{array}$ & Percentage \\
\hline Dermatitis .. $\quad$. & 42 & $36 \cdot 2 \pm 4 \cdot 4$ & 20 & $35 \cdot 1 \pm 6 \cdot 3$ \\
\hline $\begin{array}{l}\text { Eosinophilia } \\
(\geqq 10 \text { per cent.) }\end{array}$ & 7 & $6 \cdot 0 \pm 2 \cdot 2$ & 3 & $5 \cdot 3 \pm 3 \cdot \widehat{\delta}$ \\
\hline $\begin{array}{c}\text { Leukopenia }(\leqq 3,000 \\
\text { leucocytes/c.mm.) }\end{array}$ & 8 & $6 \cdot 9 \pm 2 \cdot 3$ & 1 & $1 \cdot 8 \pm 1 \cdot \stackrel{?}{7}$ \\
\hline $\begin{array}{ll}\text { Proteinuria ... } & \ldots \\
\end{array}$ & 7 & $6 \cdot 0 \pm 2 \cdot 2$ & 2 & $3 \cdot 5 \pm 2 \cdot 4$ \\
\hline Total Patients .. & 116 & & 57 & \\
\hline
\end{tabular}

The Table shows that dermatitis occurring in association with gold therapy had no correlation with the E.S.R. In other words, the number of cases of dermatitis was equally high regardless of the level of the E.S.R. The same was also true of eosinophilic reactions. On the other hand, the cases with leukopenia $(\leq 3,000 / \mathrm{c} . \mathrm{mm}$.) are seen toi be more numerous in the group of cases with an E.S.R. of $\leqq 30 \mathrm{~mm}$./hr. Our material, however, is not sufficiently large to make this difference statis-כ tically quite definite (difference between percentages $\frac{D}{D}$ is $5 \cdot 1 \pm 2 \cdot 8$ ). A grouping of the same type is also seen in the cases with proteinuria, although this ${ }_{\sigma}^{N}$ shows no statistically definite difference.

\section{Discussion}

Evaluating the nature of gold complications on the basis of our series of cases, it would seem that dermatitis and eosinophilic reactions are chiefly of an allergic nature, and for this reason their incidence 0 
is the same, regardless of the stage of activity of the disease. This seems quite natural, since quantities have no bearing on the onset of an allergic reaction. On the same basis, leukopenia and proteinuria would be toxic conditions. In this light it would be readily comprehensible why these reactions appeared to be more frequent when the E.S.R. was low, and when, for the reason referred to above, the gold concentration in, for instance, the bone marrow and the kidneys was able to increase to a higher level than in the active phase of the disease.

\section{Summary}

The relationship between the erythrocyte sedimentation rate and complications during gold therapy were studied in 173 patients with rheumatoid arthritis. No correlation with the E.S.R. was seen in cases in which dermatitis or eosinophilic reactions developed during gold therapy, but the incidence of leukopenia and proteinuria was higher in patients with a low E.S.R. It is suggested that dermatitis and eosinophilic reactions should be regarded as chiefly allergic, whereas leukopenia and proteinuria are more in the nature of toxic reactions to the gold therapy.

\section{REFERENCES}

Ellman, P., Lawrence, J. S., and Thorold, G. P. (1940). Brit. med. J., 2, 314 .

Goldie, W. (1939). Annals of the Rheumatic Diseases, 1, 319.

Lawrence, J. S. (1953). Ibid., 12, 129.
Rapport entre la vitesse de la sédimentation globulaire et les complications de la chrysothérapie dans l'arthrite rhumatismale

\section{RÉSUMÉ}

On étudia chez 173 malades atteints d'arthrite rhumatismale le rapport entre la vitesse de la sédimentation globulaire et les complications de la chrysothérapie. On ne trouva aucun rapport dans les cas de dermatite et d'éosinophilie survenant au cours du traitement par des sels d'or mais la leucopénie et la protéinurie furent plus fréquentes chez les malades à la vitesse de la sédimentation globulaire basse. On suggère que la dermatite et l'éosinophilie doivent être considérées comme réactions essentiellement allergiques tandis que la leucopénie et la protéinurie constituent plutôt des réactions toxiques à l'or.

Relación entre la velocidad de la sedimentación eritrocitaria y las complicaciones de la crisoterapia en la artritis reumatoide

\section{Sumario}

En 173 enfermos con artritis reumatoide se estudió la velocidad de la sedimentación eritrocitaria en relación a las complicaciones de la crisoterapia. No se encontró relación alguna en casos de dermatitis o de reacciones eosinofílicas ocurriendo durante el tratamiento por sales de oro, pero la incidencia de la leucopenia y de la proteinuria fué mayor en enfermos con velocidad de sedimentación baja. Se sugiere que la dermatitis y las reacciones eosinofílicas deberían considerarse como reacciones principalmente alérgicas, mientras que la leucopenia y la proteinuria representarían más bien reacciones tóxicas al oro. 